\title{
A Shallow Grave
}

By late summer 1943, my family had come up with yet another inventive idea for a hiding place for me. This time it was within the Arbeitslager, the labour camp, right inside the barracks. It was important that I make the move before the autumn weather set in, as I could not have gone on much longer living the way I did. I could not have endured a winter at the brickyard. My life there had also become a constant battle for survival, and my luck seemed to be running out. It was time to move on. We didn't know if the camp would be any safer, but in any case there was no other alternative. I would at least be together with my family and better protected from the elements.

But first I would need to get inside the Lager. The only way, we decided, was by joining up with the inmates on their way back to the camp in the evening before they reached the camp gates. But before that, I needed to familiarise myself with the route the prisoners took, a distance of some five to six kilometres, by following them at a distance and finding the best place to sneak into the column of prisoners. I did this over several days, exploring the route carefully, in my own time. The spot chosen as the most suitable was fairly near the camp gates. We felt there would be less chance of being picked out by the escorting guards if I would only be marching with the prisoners for a short distance.

On the pre-arranged day, I left the brickyard in good time, well ahead of the prisoners, and made my way to an area dotted with mounds of slag-metal waste from the steelworks along the path the inmates would be taking on their way back to the camp. I then hid behind a slag-heap and waited for the columns to appear. It was early evening when I first saw the shuffling inmates coming into view from two different directions, one from the brickyard, which I was to join up with, and the other from the direction of the steelworks, a little farther away. As the middle of the column drew level with me, I jumped forward deftly, merging with the marching ranks. My brothers, Izak and Leizer, knew the exact spot and were on the lookout for me, keeping to the outside of the 
column so they could shield me from the eyes of the escorting guards. Flanked by my two brothers, I linked arms with them to support myself and make myself appear taller. As we marched along, I had some difficulty keeping in step with the others, and was pushed forward by the men from behind, as they were not allowed to slacken off, but I soon got the hang of it by lengthening my stride, and letting my brothers help me along.

As we approached the Lager, the camp gates were swung open by two guards, one at each gate. The person I understood to be the camp commandant, Zwierzyna, was standing with his cohorts and guard dogs next to the sentry-post as the five-abreast column filed past. A Jewish policeman kept yelling out "Mützen ab, Augen links" (caps off, eyes left). I managed to slip through without any trouble. Once past the gates, the prisoners quickly dispersed, each towards his respective barracks, and my brothers took me to theirs. The column from the steelworks soon followed, with my father and Abram among them. I immediately began familiarising myself with the camp routine. The first lesson I learned was that we were no longer ghetto inmates; we were now Häftlinge, prisoners. I must have been the only young Häftling who had willingly imprisoned himself! Soon after, the hungry prisoners started to form up with their mess tins for the evening soup ration they waited for all day. Inside our barracks that evening, I was happy to be reunited with my father and later with my mother, for the first time since the ghetto was liquidated more than five months earlier. I was overjoyed to be with them again; it was comforting and reassuring merely to be in their presence. I was shocked, though, to see how bad Father looked, how different from how he'd been when I had last seen him. Mother could not remain with me long that evening, as "free-time" was soon over and she had to return to the women's barracks before lights-out, when the curfew would begin.

That evening I learned why Father looked so gaunt. He had been assigned to hard labour in the WVHA section, unloading wagons of scrap iron and iron ore with a shovel; a shovelful of ore is unbelievably heavy. This had a terrible effect on him. My father was now in his late forties, and had hitherto been strong and energetic, but the punishing work at the steelworks had taken its toll. These vital iron ore supplies kept coming from neutral Sweden throughout the war, and fed the blast furnaces of Nazi-occupied Europe, greatly assisting the war effort. Sometimes the ore arrived in freight cars with 
Russian markings, which we observed on the sidings near the camp. We were very curious about anything Russian. These long wagons, made of solid steel, were enormous compared to the smaller German or Polish wooden boxcar variety. Father said he was convinced that Germany would never win the war: "The Russian steel output must be so immense that they can afford to build freight cars out of precious steel instead of cheap timber," he'd say. "Can you imagine how many tanks and heavy guns they must be turning out? Everything about Russia is so vast, it just cannot be conquered; eternal Russia will be Hitler's graveyard." Poor Father tried to take heart from whatever he could-he dearly desired to survive long enough to see Nazi Germany crushed.

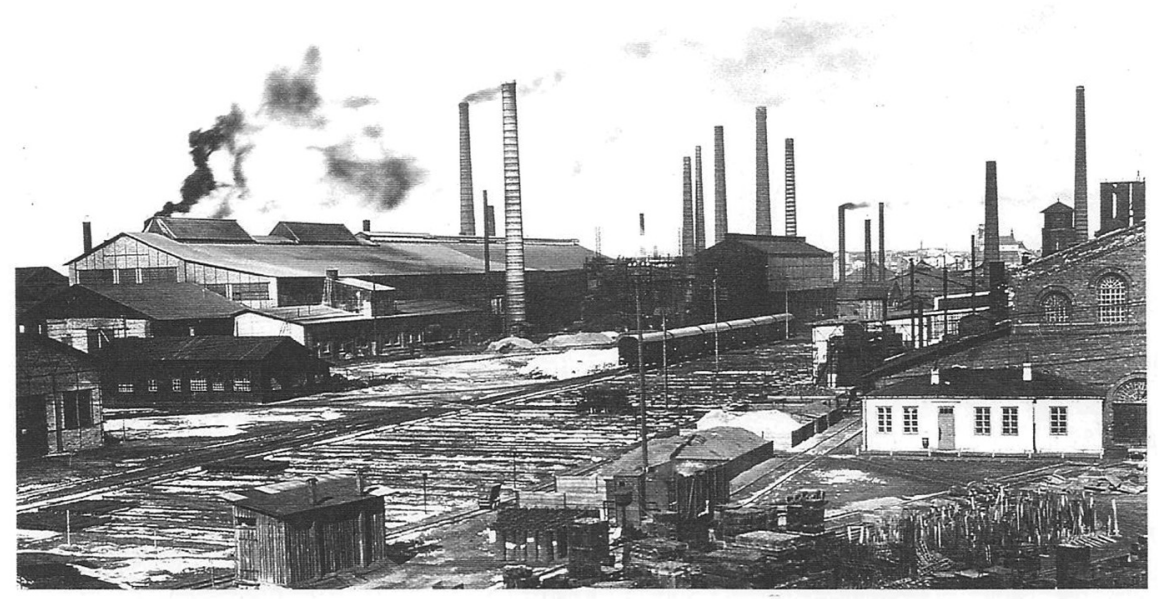

A partial view of the vast Ostrowiec Steelworks.

It was not, as you may have guessed, enough to just steal into the camp; I now had to somehow hide from the Germans. Again, my ever-resourceful family had an ingenious idea for a hiding place. It was in the form of a dugout below the bottom-tier bunk that my father and brothers slept on. Below the boards of the bottom row of bunks there was a void about $25 \mathrm{~cm}$ in height. This space was hidden from view by the boards that supported the bunks. To start with, two of the boards had been prised up and the nails removed. Enough of the 
soil that formed the ground under the space was scooped away and shoved to the sides to accommodate me, in a prone position on my back. However, the space was too shallow for me to turn over, or to lie on my side. The two loose boards were then replaced on top of me, and covered over with the prisoners' straw-filled mattresses.

My brothers and father had no tools with which to prepare the dugout; no tools whatsoever were allowed in the camp. However, Izak had managed to conceal on his body a piece of metal from the steelworks, with the aid of which he had scraped away at the compacted hard soil during the night, using his bare hands.

At long last I was now able to have my hair cut. Izak borrowed a pair of clippers from the camp barber and cropped it short-oh, what sweet relief! Soon after I got into the Lager, Izak was assigned the same punitive work as my father, shovelling heavy iron ore. This was considered the hardest task of all. Doing twelve-hour shifts, one could not survive such punishing work for long on camp rations. What's more, Izak helped Father out with his workload whenever possible. My father was born in 1893, and was by then almost fifty years old. It pained us to see him return to the barracks at night utterly drained and exhausted. I will never forget how the whites of his eyes stood out; his face and hands were covered in red iron ore dust-he was but a shadow of his former, robust, self. Mother, as I mentioned, was working in the camp kitchens, which at least had its compensations. And Abram's job was to crawl inside the furnaces after they had cooled off, and to use a special tool and hammer to chop out any fire-bricks lining the furnace walls that had been damaged and needed to be replaced. He was just fourteen years old.

The Lager was situated near the Częstocice sugar-beet refinery, not far from the steelworks. The camp consisted of a number of long wooden barracks, with no windows aside from narrow raised skylights running the lengths of the roofs. The barracks stood in straight rows, all facing the Appellplatz (assembly ground). The camp perimeter was built in a square and enclosed by three rows of electrified barbed-wire fencing, with four watchtowers, one in each corner. Ukrainian sentries manned these day and night with mounted machine-guns trained on the camp fence and the barracks, to spy on the prisoners, and revolving searchlights illuminated the fence during the hours of darkness. 
There was no escape; the only way in or out was through the camp gate. Two sentry boxes, painted with the customary red and white diagonal stripes, stood on either side of the camp entrance gate. The guardhouse and barrack block housing the German SS and Ukrainian guards was situated just outside the camp fence, near the entrance gate. Thus, the guards had a clear view of the entire camp and the barrack doors, which all faced the assembly ground.

Inside each of the barracks there were three-tiered wooden bunks (plank beds) running the length of the barracks on both sides like shelves, with a gangway down the middle. Narrow rectangular bags the width of the bunks, made out of coarse sacking and filled with straw, served as mattresses. The straw came through the loose weave and was irritating and itchy. There was no change of clothes: the clothing you stood in was worn day and night, and no underwear was issued. You had what you came in, and this was disinfected from time to time. A small, wood-burning cast-iron stove stood in the middle of each barracks, with the stove-pipe running through to the roof. Every prisoner was issued with one blanket. This was insufficient to keep warm, so on cold nights our family would huddle closely together for warmth.

There were separate quarters for women, who were few in number. The Germans didn't consider women capable of hard labour, and they had enough men. After the day shift, men and women could mingle before and after "soup time" until lights-out and the start of the curfew, which varied according to the daylight hours. After curfew, it was advisable to stay in one's barracks or risk being shot at from the watchtower if caught in the beam approaching the electrified fence. If a prisoner had dysentery, as we often did, it was prudent to stay well clear of the fence when making a dash for the latrines.

There was only one latrine and washroom hut that had to serve the entire camp. There were two doors: women entered at one end and men at the other. A low timber partition provided a modicum of privacy. The open latrine had a crossbar running the length of the shed, serving as a thigh support, above a rectangular pit. The only time I could make use of the latrines was after dark, before the curfew. My legs didn't reach to the floor, so I had to watch my balance-the pit was quite deep! The stench from the open cesspit was overpowering, and from time to time, our captors formed a Scheisskommando ("shit detachment") from amongst the prisoners to reduce the level of excrement to stop it from 
overflowing. The reduction was done by passing buckets, hand-to-hand, to another freshly-dug pit. Needless to say, this was considered one of the most abhorrent tasks - and was all part of the systematic plan to break down our morale and degrade the inmates. The Germans referred to us as Untermenschen (sub-humans), who deserved no pity and who could be killed with impunity and without remorse. One didn't become a sub-human overnight, of course. It was a gradual process. Inevitably, this treatment led to a degree of breakdown in morals among some of the young men and women, who felt they didn't have long to live and so lived for the moment.

German guards were fearful of the infectious diseases which took hold in the camp from time to time, so they tried to keep their distance. They rarely ventured inside the barracks and never came at night, so there was no need for me to hide inside my "coffin," as I thought of it. When they entered the barracks in daytime, it was to mete out punishment or to carry out the occasional barrack inspection. The ever-present danger was when the labour security officers Goldsitz and Rhade, accompanied by Ukrainian guards, came onto the camp square for Zahlappell, roll-call, in the early hours. One could never be sure they would not enter the barracks in search of some missing prisoner who failed to report for roll-call, so I always remained hidden flat on my back in my dugout. I was able to emerge by myself and to hide again by myself, which is the only thing that saved me. I would only come out after the guards had left the camp with the prisoners, when the blowing of whistles and the barking of orders and dogs had ceased. I remained inside the barracks, keeping close to my bunk, never venturing out during daylight. If danger lurked, I was able to quickly slide sideways, on my back, into the dugout, and to replace the boards on top of me. It was on one occasion, as I was lying down below, flat on my back, with the boards almost touching my face, that I realized that it was like lying inside a wooden coffin in a dank grave. I felt breathless down below, so I had to come up for air as soon as it was safe to do so. To this day I have a phobia about lying on my back; it brings back traumatic memories, and I'm unable to sleep that way.

Now and then there were the barrack inspections, when each prisoner had to stand rigidly to attention in front of his bunk. As the German officers entered the barracks, a cold shiver would run down my spine as the barracks' senior brought the prisoners to attention 
with the command: "Achtung! Mützen ab" (Attention, caps off). These were terrifying moments for me; I could hear every sound down below in my "coffin" as the SS guards passed within a few feet of me. A sud den cough or sneeze could have spelled disaster for me and my family. Father told me to hold my nose, which would stop me from sneezing. I also kept my eyes closed, so I could hear better. I held my breath while the inspection-party walked past the line of prisoners, and only relaxed when I heard them move away from my bunk. A little while later, the order Weitermachen was heard, as they left the barracks and the inmates eased off and dispersed. Everyone in the barracks knew of my presence there. I was, of course, a source of danger to them, if discovered, but nonetheless they liked me and considered me their mascot. It was tacitly understood that should I be reported, my big brothers would not hesitate to exact their revenge. We were pretty sure, though, that it would never come to that. Most of the men knew each other and their families intimately from way back, and a close bond existed between them. It may have been different in the larger concentration camps, where strangers of different nationalities were lumped together and some contemptible person may have been tempted to "rat" on his fellow in the hope of saving his skin or earning an extra crust. Extreme hunger can do terrible things to people.

Roll-call was at five-thirty in the morning, after reveille at five. At six a.m., two separate columns of workmen set out from the camp, going in opposite directions towards their respective work places. The day shift lasted until just before nightfall, seven days a week, with the occasional Sunday off. The daily food ration consisted of 180 grams of coarse black bread that tasted as if it contained sawdust and two ladles of a watery soup, usually made from cabbage or turnip and the odd potato floating around, with little protein. As in other camps, a favourite talking point was of a thick soup where the spoon would stand up on its end. In the morning the prisoners received a ladle-full of black ersatz coffee, apparently made from sugar beets, and a hunk of sticky, and sometimes mouldy, bread. If the bread was too mouldy, it was best soaked in water, and after the mould floated to the surface you could squeeze it out. I was not entitled to any rations; I couldn't even be seen approaching the vat on the Appellplatz where the slop was doled out. My family shared their rations with me, which meant less for them. Each prisoner was responsible for carrying his menaszka (mess tin) with him, and a spoon 
if he had one. If he had no spoon, he would have to slurp his soup. To each, the tin was his most prized possession. Some people only had a tin can for a mess tin, with a piece of wire attached for a handle. If lost, the tins were difficult to replace, and "no mess tin-no soup" was the camp rule. Hence they were kept about the prisoner's person, usually tied to the waist with string. The same applied to any spare piece of clothing a prisoner may have had, as there was nowhere safe to keep it. Leather shoes were unobtainable, and when their shoes wore through, the prisoners were issued with wooden clogs instead. We called them Hollenderki, Dutch maidens.

The inmates in our Lager wore a motley variety of worn out, shabby clothing. You only had what you arrived in, and when that fell apart, prisoners were issued with pasiaki, a blue-grey striped pyjama-like outfit of shirt and pants. In the early days, some prisoners were brought in from other camps wearing these curious stripes, which were hitherto unknown to us. The Star of David armband that was worn in the ghetto was discarded in the camp, for here we were all caged in, and there was no need for the Germans to set us apart from the rest of the population. There were no prisoner markings either, as there were no political prisoners in our camp, only Jews. There weren't any names, nor even numbers like in Auschwitz; prisoners were simply addressed with a stabbing finger movement and a piercing shriek: "Du Jude!"

One day a grisly discovery was made when a sack tied with string was found lying against the camp fence. Inside it were found two severed heads that turned out to be those of my cousins, Moshe and Yossel Berman. In better times, it had been Moshe who would take me to football matches in support of the local team, KSZO. The two brothers, as I recounted earlier, had escaped from the ghetto before its liquidation to be hidden by peasant farmers in the nearby village of Denków. After the two peasants, who were in it together, had presumably laid their hands on their money and my cousins were no longer of any use to them, they butchered them in the most gruesome manner. Their severed heads were thrown against the camp fence in a macabre display of hatred and contempt for their erstwhile Jewish neighbours, and their decapitated bodies were dumped elsewhere. When the headless bodies were later brought into the camp for burial, it was found that their wounds were consistent with having been run through with pitchforks, several times. They must have made the fatal mistake of keeping all 
their money with them-or perhaps the peasants discovered where they had hidden it.

From time to time, the camp guards would carry out searches to try and extract any valuables they could from the wretched inmates to stuff their own pockets. One day they declared that they had good reason to believe there were American dollars hidden in the camp which had to be handed over immediately, promising that no harm would come to those who complied. Of course, no one believed them, and no dollars were forthcoming. The guards then carried out a thorough body search. All they found was a few dollars on two brothers, sewn into their clothing. As a result, they were taken out onto the Appellplatz, where the other prisoners were to witness their execution. One brother shouted out a desperate last plea, imploring the executioners to shoot him first. "I don't want to see my brother die!," he pleaded. Surprisingly, the Germans obliged and granted him this last wish.

One prisoner in particular, a Jewish policeman named Puczyc, who was not a local, was to be avoided. He was unpredictable and could turn violent; no doubt believing that this would curry favour with his superiors and help save his own skin. One day, he appeared from behind our barracks and came across my mother boiling up some potato peelings in a mess tin standing on bricks over some flaming twigs. She had smuggled the peelings from the camp kitchens for her children. When Puczyc realised what she was up to, he kicked it over with his polished kneehigh boot. A local man would not have done this to her: our family was well-respected before the war. Father had done much for the good of the community and the needy of our town. Even in this nether world, some people sought his counsel and came to listen to a Dvar Torah, words of wisdom, which he liked to quote from the Hebrew Scriptures.

As there was no rabbi left alive, it fell upon Father to conduct clan-destine services on the High Holy Days in our barracks. There were no prayer-books, but my father knew them by heart. As worship was forbidden, the prayer meetings had to be short, so he only focused on the salient prayers. I sat on my bunk and listened; a hushed silence filled the barracks as Father offered prayers in his melodious soft voice, the strains of which carried much feeling. I can still hear the poignancy of Odom Yesodo Meofor; "Man's origin is dust and to dust he returns and gets his bread at the peril of his life." Another passage that stands out in 
my mind said, "In Thy hand is the soul of every living creature; the soul is Thine, and the body is Thy work, O Lord of the Universe, have pity on Thy creation." The atmosphere in the barracks was heavy with emotion. In view of our plight, these solemn words took on an especially deep significance. I remembered these poignant words, and as I got older I understood their meaning with greater clarity. I realised just how meaningful they were, and how appropriate to the situation. Not everyone joined in the prayers, of course. Many abandoned God, just as $\mathrm{He}$ had abandoned them. From the depths of despair they had cried out for help, but they had not been answered-God remained silent, and the world looked on and said nothing.

Although there was nothing to laugh about, a sort of bleak humour emerged in the Lager - we were Jews, after all! Earlier, in the ghetto, we had been too shocked to make light of the events that had befallen us, and there were more important things to think of at a time when everyone was preoccupied with avoiding deportation trains and a bullet to the head. But as time went on, we became more accustomed to our situation and could afford to raise a laugh at our predicament. Once we were incarcerated in the Lager, caged in like animals, it was final-what were we to do? "What was, was, and is no more," as one sardonic ditty went at the time. The opening words to another ditty, steeped in irony, presumably alluding to an old flame in the good old days, went like this: "Where were you when the money was there? Now you're here when the money's all gone!" In the camp there was time to think, and a cheerless humour emerged, helping people to cope with the grim reality and to preserve their sanity.

A Lager jargon also developed. It was made up of sardonic, selfmocking plays on words, and was a form of escape from reality. The expressions were full of pathos about our plight and precarious existence, about the daily routine, and about the food-or rather the lack of it. People joked bitterly: "Here every day is like Yom Kippur (the Day of Repentance, the central fast day of the Jewish calendar); we all dress up as if it's Purim (a holiday partially marked by the wearing of costumes), and we live in a Succah (wooden hut, such as the one used on Sukkot, the holiday of Tabernacles)," as if camp life could compare with the joyous festivals of the past. Nicknames were invented and given to various guards and cruel tormentors. Hitler became Hittlemacher, capmaker, in Yiddish, and so on. This jargon spread from ghetto to ghetto 
and camp to camp by word of mouth. The usual phrase to encourage someone on the brink of giving up the will to live was "Gibt nisht up die bonne"-don't surrender the ration coupons. Satirical songs and poems were written. All of this helped to ease the inmates' hardship and raise their morale, which the Nazis were determined to break-it was a form of spiritual resistance.

Prisoners eagerly exchanged scanty bits of information about the course of the war gleaned from Polish workmen at the steelworks, some of whom may have had access to clandestine radio reports from London or the Underground. When we heard by way of rumour that the Wehrmacht had suffered a significant defeat at Stalingrad some months before, we could scarcely believe it. This marked the tide of war changing, but we didn't know it at the time; now we were aware of the full extent of the Russian victory. This piece of sensational news lifted our spirits and raised our hopes. Prior to the battle of Stalingrad, many of us had believed that the Germans would win the war and that our chances of survival were slim.

Any information about the progress of the war was hard to come by. The Ukrainian guards had orders not to talk to prisoners and, regardless, would never admit to German reversals. To the contrary, they liked to taunt us, saying "Russki kaputt!". The suggestion that Soviet Russia was done for, was very disheartening for us, as we looked to it for our salvation. In our part of the world, the only direction from which any rescue could come was the East-the Western Allies were a distant prospect.

By this time the prisoner population started to swell, with inmates being brought in from other prison camps like nearby SkarżyskoKamienna, and some from as far away as Warsaw. It was from them that we first heard about the epic Warsaw Ghetto Revolt, when the ghetto inmates rose up against their Nazi oppressors, and about the indescribable destruction and enormity of crimes committed elsewhere. They also brought with them songs of defiance and bravery, along with more nostalgic and plaintive songs. One indignant song said, "Tzu bin ich fun ein schtein geboir'n...?" Was I born of a stone and did a mother not hold me in her arms? Another poignant one was "Es Brent" ("Our Village Burns"). This became a rallying cry; it carried a message of resistance couched in the lyrics: "Evil winds full of anger rage and ravage and yet you stand there looking on with folded arms. Should our shtetl with us together, 
go up in ash ' $n$ fire, and when the slaughter's over, leave just charred and empty walls. . . Brothers! Grab the buckets, douse the fire with your very blood, show what you're made of! Brothers don't just stand there looking on with folded arms, as our poor little shtetl burns....

One piece I liked, Matyushka Russiya, came a little later. It was a wistful song, full of yearning for Mother Russia, which symbolised freedom from the Nazis. I have not heard it sung since those dark days. Sung in Yiddish, these are but a few of the lyrics, as I remember them:

Matyushka Russiya, Oh, how deeply I pine for you. (Chorus)

I yearn for the Russian lieder (melodies), for the heartfelt brothers and sisters.

I yearn for the Russian mentsch (being)

that is resolute and sturdy.

I yearn for the Russian soul, who is as free as the wind.

Suddenly, a raging tempest on the earth is unleashed.

Wild beasts run amok, people hunted down and trampled on.

War, War is their cry!

Matyushka Russiya, Oh, how deeply I pine for you. ...

At that time, we all had immense solidarity with Soviet Russia. All our hopes rested on the valiant Red Army who bore the brunt of the war, and only they, we believed, would come to our rescue. Only "Mother Russia" evoked any hope as far as we in Poland were concerned. Inmates complained bitterly, "Surely, the outside world must know what is happening and what the Nazis are doing to us!" The inmates felt abandoned by a callous and uncaring world that remained silent, for their silence encouraged the Nazis. People naively thought that the cynical American and British leaders would have much to answer for, when the war finally came to an end, for being indifferent to the fate of those doomed to destruction.

As a result of the arrival of newcomers from other prison camps, the regime in our Lager progressively worsened; conditions and sanitation deteriorated further. Hungry and frail bodies attract disease, and a 
typhus epidemic broke out yet again, with many dying as a result. I was plagued with body lice, which were impossible to get rid of. As lice spread disease, particularly typhus, the prisoners were sent to periodic showers and for de-lousing sessions, where they were dusted down with a lice powder which I, as an illegal inhabitant of the camp, could not take advantage of. I was infested with the blood-sucking parasites, and they tormented me, particularly at night when I was trying to sleep. They were in my hair, although it was closely cropped, and in my clothes, particularly in the seams. Somehow the lice, especially the nits, got into the most hidden crevices. I would sit for hours on my bunk, carefully going over each piece of clothing, searching for the plump little beasts, crushing them between my thumbnails. They got so fat from feasting on my blood that when I squashed them they burst with a click, revealing traces of human blood. The itchiness almost drove me crazy. I couldn't stop myself from scratching until I lacerated my skin. The pain seemed preferable and easier to endure than the constant itching. Strangely enough, at the brickyard I had never suffered from lice, although my hair had been long. I suppose there was no one to catch it from, and I had tried to keep clean by washing in the lake.

Then there were the elusive jumping fleas that were difficult to catch. These mainly inhabited the barrack floor and liked to go for your ankles and legs. And there were also the nasty-smelling bedbugs that one had to contend with. These were easier to locate, as they were dark brown in colour. When crushed they emitted an unpleasant and peculiar sweet odour. Bedbugs, compared to lice and fleas, are large, and they are mainly active at night. They can give a nasty bite that leave a little red bump for several days. As it was not possible for me to go with the inmates to the showers and de-lousing sessions, I had to make do with rubbing myself down with a wet rag inside the barracks. Due to lack of nutrition and poor hygiene, I suffered a lot from festering sores and painful boils. The long days spent in the Lager were extremely boring with nothing for me to do, apart from searching for the noxious little parasites. I only had the evenings to look forward to, when the family returned to the barracks after the daily work shift.

Now and then the barracks were fumigated. This was an anxious time for me, as the equipment was operated by German sanitary personnel, in white overalls, and due to the harmful fumes, I could not remain inside my dugout below the bunk. Even outside the barracks the chemical 
fumes had a choking effect on the inmates. Fumigation was performed in the evening after soup time, while the prisoners sat outside on the ground. I was shielded by my family until we were ordered back into the barracks. The camp grounds were covered with black shingle from the steelworks smelter; there wasn't a shrub or even a blade of grass to be seen. Neither trees nor any other greenery grew in the Lager. There were no birds or birdsong, and no butterflies. Even mice and rats kept away from the camp; they would hardly find a crumb. Only flies were not deterred.

By late autumn 1943, the situation in the camp was worsening by the day; there were now more frequent shootings and acts of unspeakable cruelty. As I was afraid of being discovered, I went back to the brickyard for a short period, and as before, I sneaked back into the camp with the prisoners when we thought that things had calmed down somewhat. One day, the two partisan brothers Sztajn were captured. I knew them, as I used to come across them during my time in the vicinity of the brickyard. I'm not sure exactly where and how they were caught, but the two brave men were brought into the Lager and hanged on the Appellplatz, having first been subjected to torture; they were apparently in a terrible state. The entire camp was forced to stand and watch as the stools were kicked from under them. The bodies were left swinging on the gallows for hours as the inmates were made to stand and watch. The prisoners stood in stony silence, full of admiration for two brave men who had possessed the courage and an opportunity to fight back.

At around this time, one morning following the Appel (roll-call) the prisoners were made to stand for hours on the assembly ground. As they waited, Moishe Gutholtz, an orderly from the Krankenstübe (sick bay), cracked and could take it no longer. He turned on his tormentors, railing at them: "You vile murderers, what do you want from us?" Then the burly Gutholtz threw himself at Werkschutzführer Rhade, grabbing him by the throat from behind with one arm while with the other he removed the Luger from its holster and thrust it in his ribs. Moishe pulled the trigger, but the gun jammed, so he briefly let go of the German's neck to pull the lever back so he could fire. During that moment, Rhade recovered and started to grapple with Gutholtz, and they both fell to the ground. The Ukrainian guards rushed up but could not take proper aim at Gutholtz, as he and Rhade were rolling in the 
dirt in each other's grasp. The guards, unable to take aim, beat the courageous man senseless with rifle blows to his head and body. When he finally let go of Rhade they shot him, but he still held on to the gun in his tightly clenched fist, though he appeared to be dead. Incredibly, after Gutholtz's body was carried away by his fellow inmates to be buried, he whispered to the burial party: "Brothers, cover me lightly." An alert German caught on to the situation and ran up. Reaching for his Luger, he put it against Gutholtz's temple and pulled the trigger. The Germans and Ukrainians then went wild, striking out in all directions, firing at random into the line of prisoners, killing several and injuring others. Some inmates tried to rush the guards, while others tried to calm them and hold them back. They had no chance; there was no escape and nowhere to run to, except into the arms of hostile Poles. Resistance was simply suicide, but by holding back, they had a chance, however slim, of surviving to tell the world of the horrors they had endured. Only survival was paramount; nothing else mattered. ${ }^{7}$

Towards the end of 1943, in order to cover the losses incurred, hundreds of prisoners from other prison camps were brought into our Lager. They came from such places as Piotrków, Radom, and Płaszów, near Kraków-over five hundred prisoners came from the latter. These were referred to as Krakowiaks, after the folk dancers of that province. As a result of the squalor and poor sanitation, yet another epidemic broke out. Thankfully, I was not infected and in my entire time there never got seriously ill, apart from colds and of course diarrhoea, which was so common as to be not worth mentioning. I must have built up immunity to typhus, which is highly contagious. Had I fallen ill, there would have been no chance of treatment. I took heart from the saying that Father liked to repeat: "What doesn't kill you makes you stronger."

One day, Polish steelworkers tipped off the Germans that several Jews were hiding at the steelworks. They guided them to where they were sheltering, and indeed six young men were discovered.

7 The site where the Ostrowiec slave labour camp stood has since been turned into cultivation allotments where the locals grow their cabbages, without so much as a plaque to record what took place there. Nor is there any record of the former Jewish community. 
The Germans in turn left it to their Ukrainian lackeys to mete out the appropriate punishment for attempting to hide. The savages cast them alive, one by one, into the roaring furnace at the foundry. One of the victims was my mother's cousin, by the name of Fiksenbaum. After this hor-rific incident, it was time to put into effect my longplanned escape to Warsaw. We could not risk leaving it any longer. I didn't want to be separated from my family, but my parents urged me to go, before time ran out. 